\title{
Preparation and Structure of Poly(gold)telluronium Salts
}

\begin{abstract}
Klaus Angermaier, Hubert Schmidbaur*
Anorganisch-chemisches Institut der Technischen Universität München, Lichtenbergstrasse 4, D-85747 Garching, Germany

Z. Naturforsch. 51b, 879-882 (1996), received December 22, 1995

Telluronium Complexes, Gold(I) Complexes, Tri- and Tetra(gold)telluronium Salts, Auriophilicity, Crystal Structure

Tris[(triphenylphosphine)gold(I)]telluronium tetrafluoroborate (1) was prepared from the corresponding oxonium salt and bis( $t$-butyldimethylsilyl)tellurium in dichloromethane at $-78^{\circ} \mathrm{C}$. The product forms yellow crystals, thermally stable to $125^{\circ} \mathrm{C}$. It was identified by standard analytical and spectroscopic techniques, including a single crystal X-ray diffraction study. In the crystal lattice, the cations form tellurium-capped triangles of gold, which are associated into dimers through short intermolecular $\mathrm{Au}-\mathrm{Au}$ contacts, resembling those in the corresponding sulfur and selenium compounds. - The reaction of $\left(t-\mathrm{BuMe}_{2} \mathrm{Si}\right)_{2} \mathrm{Te}$ with four equivalents of $\left[\left(\mathrm{Ph}_{3} \mathrm{P}\right) \mathrm{Au}\right] \mathrm{BF}_{4}$ in tetrahydrofuran at $-78{ }^{\circ} \mathrm{C}$ gives a tetranuclear compound, $\left\{\left[\left(\mathrm{Ph}_{3} \mathrm{P}\right) \mathrm{Au}\right]_{4} \mathrm{Te}\right\}^{2+} 2 \mathrm{BF}_{4}^{-}(\mathbf{2})$ which differs from $\mathbf{1}$ in its analytical and spectroscopic data. Its structure could not be determined, but it is assumed that the dications have a square pyramidal geometry.
\end{abstract}

\section{Introduction}

Gold has a very special affinity to tellurium. In the world of minerals, tellurium is the only metalloid to form binary compounds with gold [1]. Binary anionic species have recently been prepared in a variety of stoichiometries and structures, which show a unique relationship of the two elements [2-7]. Gold organotellurides ( $\mathrm{RTe} A u)_{n}$ and their complexes were obtained only recently and our knowledge is limited to compounds with very bulky substituents $[8,9]$.

The current interest in the gold/tellurium system arises from a relevance of pertinent research for semiconductor technology, material science, and pharmacology. This resembles the situation with the analogous selenium/ and sulfur/gold systems, for which extensive investigations were initiated at a much earlier stage.

Complex units $\mathrm{LAu}^{+}$(with $\mathrm{L}$ a standard electron donor ligand) are known to aggregate at sulfide or selenide centers $\left(\mathrm{E}^{2-}\right)$ to give mono-, di-, tri-, and finally tetranuclear coordination compounds of the type $\left([\mathrm{LAu})_{n} \mathrm{E}\right]^{(n-2)+}[10-12]$. These units can be further aggregated into dimers or polymers through $\mathrm{Au}-\mathrm{Au}$ contacts (auriophilicity [13]). For $\mathrm{E}=\mathrm{Te}$ only very few examples of this series have

\footnotetext{
* Reprint requests to Prof. Dr. H. Schmidbaur.
}

been confirmed [8,9], and we have therefore become engaged in a study oriented towards the synthesis of the species with $n=3,4$ which are most prominent for $\mathrm{E}=\mathrm{S}$, Se [10-12].

\section{Results}

The preparative methods providing access to poly(gold)telluronium salts can be adopted from previous studies with the corresponding sulfonium and selenonium salts. The key reaction for the trinuclear compound is the treatment of the oxonium salt with a disilyl chalcogenide $\left(\mathrm{R}_{3} \mathrm{Si}\right)_{2} \mathrm{E}$ in dichloromethane at $-78^{\circ} \mathrm{C}$.

While the trimethylsilyl compounds proved most useful in the sulfur and selenium series, the more stable $t$-butyldimethylsilyl homologues offered distinct advantages in the tellurium case. For $\mathrm{L}=$ $\mathrm{Ph}_{3} \mathrm{P}$ the isolated yield of product 1 was $33 \%$. With $\mathrm{L}=\mathrm{Me}_{3} \mathrm{P}$ only decomposition products were obtained.

$$
\begin{gathered}
\left.\left\{\left(\mathrm{Ph}_{3} \mathrm{P}\right) \mathrm{Au}\right]_{3} \mathrm{O}\right\}^{+} \mathrm{BF}_{4}{ }^{-}+\left(t-\mathrm{BuMe}_{2} \mathrm{Si}\right)_{2} \mathrm{Te} \\
\left(t-\mathrm{BuMe}_{2} \mathrm{Si}\right)_{2} \mathrm{O}+\left\{\left[\left(\mathrm{Ph}_{3} \mathrm{P}\right) \mathrm{Au}\right]_{3} \mathrm{Te}^{+}\right\}^{+} \mathrm{BF}_{4}^{-}
\end{gathered}
$$

Compound 1 forms yellow crystals, m.p. 125$127^{\circ} \mathrm{C}$ with decomposition, soluble in chloroform and dichloromethane. In the Fast Atom Bombardment mass spectrum (nitrobenzyl alcohol matrix) the mass of the cation is observed as the parent 
Table I. Crystal and structure solution data for compound $\mathbf{1}$.

\begin{tabular}{|c|c|}
\hline Empirical formula & $\mathrm{C}_{54} \mathrm{H}_{45} \mathrm{Au}_{3} \mathrm{BF}_{4} \mathrm{P}_{3} \mathrm{Te} \times 0.5 \mathrm{C}_{2} \mathrm{H}_{10} \mathrm{O}$ \\
\hline Formula weight & 1629.18 \\
\hline Crystal system & triclinic \\
\hline Space group (No.) & $\mathrm{P} \overline{1}($ No.2) \\
\hline$a[\AA]$ & $15.204(2)$ \\
\hline$b[\AA]$ & $17.877(2)$ \\
\hline$c[\AA]$ & $22.862(3)$ \\
\hline$\alpha$ & $89.23(1)$ \\
\hline$\beta$ & $72.07(1)$ \\
\hline$\gamma$ & 69.91(1) \\
\hline $\mathrm{V}\left[\AA^{3}\right]$ & 5522.7 \\
\hline$Q_{\text {calc }}\left[\mathrm{gcm}^{-3}\right]$ & 1.960 \\
\hline Z & 4 \\
\hline $\mathrm{F}(000)[\mathrm{e}]$ & 3060 \\
\hline$\mu\left(\mathrm{Mo}-\mathrm{K}_{\alpha}\right)\left[\mathrm{cm}^{-1}\right]$ & 86.00 \\
\hline Cryst. dim. [mm] & $0.25 / 0.40 / 0.45$ \\
\hline $\mathrm{T}\left[{ }^{\circ} \mathrm{C}\right]$ & -62 \\
\hline Diffractometer & Enraf Nonius CAD4 \\
\hline Scan & $\omega$ \\
\hline$h k l$ Range & $+18 / \pm 22 / \pm 28$ \\
\hline Measured reflections & 21512 \\
\hline Unique reflections & 19830 \\
\hline Observed reflections & 17006 \\
\hline$F_{0}$ & $4 \sigma\left(\mathrm{F}_{\mathrm{o}}\right)$ \\
\hline Refined parameters & 592 \\
\hline H-Atoms (found/calc.) & $0 / 50$ \\
\hline Absorption corr.: & empirical \\
\hline $\mathrm{T}_{\min } / \mathrm{T}_{\max }$ & $0.3781 / 0.9997$ \\
\hline$R^{*}$ & 0.0441 \\
\hline$R_{w * *}$ & 0.0474 \\
\hline Weighting scheme *** & $l=1.0000 / k=0.000619$ \\
\hline$\varrho_{\text {fin }}(\max / \min )\left[\mathrm{e}^{-3}\right]$ & $+1.80 /-1.72$ \\
\hline
\end{tabular}

$* R=\Sigma\left(|| \mathrm{F}_{\mathrm{o}}|-| \mathrm{F}_{\mathrm{c}}||\right) / \Sigma\left|\mathrm{F}_{\mathrm{o}}\right|$

$* * R_{w}=\left[\sum \mathrm{w}\left(\left|\mathrm{F}_{\mathrm{o}}\right|-\left|\mathrm{F}_{\mathrm{c}}\right|\right)^{2} / \sum \mathrm{wF}_{\mathrm{o}}^{2}\right]^{1 / 2}$,

$* * * \mathrm{w}=1 / \sigma^{2}\left(\mathrm{~F}_{\mathrm{o}}\right)+\mathrm{k}\left(\mathrm{F}_{\mathrm{o}}\right)^{2}$.

peak at $m / z=1508$. The ${ }^{31} \mathrm{P}\left\{{ }^{1} \mathrm{H}\right\}$ NMR spectrum of $\mathrm{CD}_{2} \mathrm{Cl}_{2}$ solutions shows only one resonance at $\delta=37.9 \mathrm{ppm}$. The ${ }^{1} \mathrm{H}$ and ${ }^{13} \mathrm{C}\left\{{ }^{1} \mathrm{H}\right\}$ spectra contain the usual phenyl multiplet and the standard set of four types of rings carbon atoms, respectively.

Single crystals of compound $\mathbf{1}$ obtained from $\mathrm{CH}_{2} \mathrm{Cl}_{2} /\left(\mathrm{C}_{2} \mathrm{H}_{5}\right)_{2} \mathrm{O}$ contain half a molecule of crys- tal diethyl ether per formula unit. The crystals are triclinic, space group $\mathrm{P} \overline{1}$, with $\mathrm{Z}=4$ formula units in the unit cell (Table I). The structure was refined from 19830 unique reflections measured at $-62{ }^{\circ} \mathrm{C}$ to $R=0.044\left(R_{w}=0.047\right)$. The asymetric unit contains two independent cations with the gold atoms $\mathrm{Au} 1-\mathrm{Au} 3$ at Te1 and $\mathrm{Au} 4-\mathrm{Au} 6$ at $\mathrm{Te} 2$, respectively, with very similar dimensions (Fig. 1, Table II). Each of these units is associated into centrosymmetrical dimers through short intercationic contacts. The inversion centers are centroids of the gold rectangles generated in the dimerization process (Fig. 2). The anions and the diethyl ether molecules have no close contacts with the dications.

The $\mathrm{Au}-\mathrm{Te}-\mathrm{Au}$ angles in the $\mathrm{Te} \mathrm{Au}_{3}$ pyramids are all much smaller than $90^{\circ}$, with individual values between $72.6(1)$ and $84.7(1)^{\circ}$. As a consequence of these small angles, the $\mathrm{Au}-\mathrm{Au}$ distances in the cation monomers are in the range from 3.074(1) to 3.515(1) $\AA$ and can all be regarded as bonding contacts (auriophilicity, [13]). The intercationic distances (Au1-Au2' and Au4-Au6') are also in the same range, indicating significant metal-metal interactions between the two monomer components. It should be noted that the intercationic $\mathrm{Au}-\mathrm{Au}$ distances can be even smaller than the intracationic distances: Au1-Au2' is the shortest of all $\mathrm{Au}-\mathrm{Au}$ contacts.

The $\mathrm{Au}-\mathrm{Te}$ distances in $\mathbf{1}$ are all close to 2.60 $\AA$, in good agreement with reference data (see references in the Introduction). The geometry of the remainder of the molecules has no unusual features. Details have been deposited.

Treatment of $\left(t-\mathrm{BuMe}_{2} \mathrm{Si}\right)_{2} \mathrm{Te}$ with four equivalents of $\left[\left(\mathrm{Ph}_{3} \mathrm{P}\right) \mathrm{Au}\right]^{+} \mathrm{BF}_{4}{ }^{-}$in tetrahydrofuran at
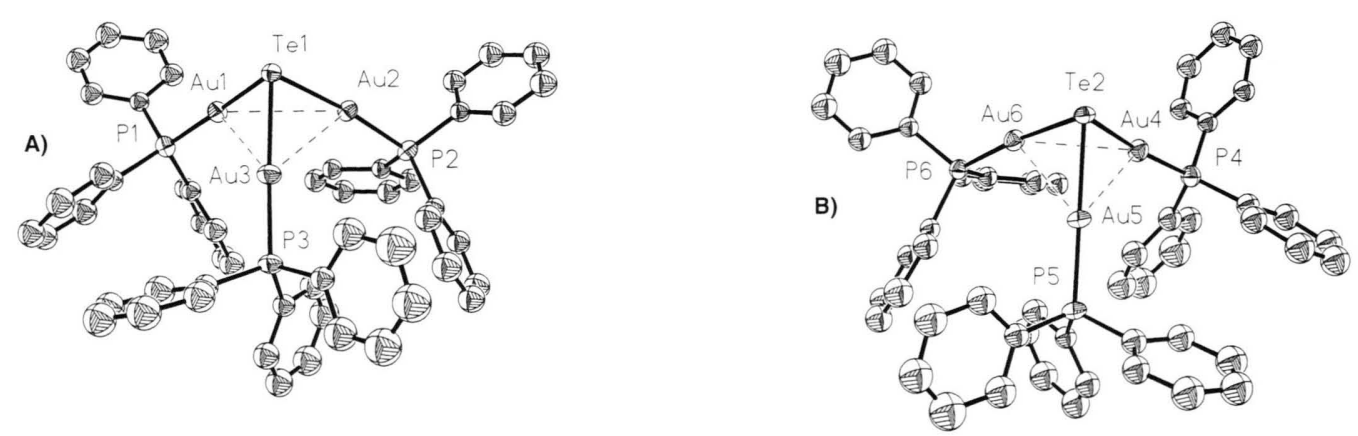

Fig. 1. Molecular structure of the two crystallographically independent monomeric units (A, B) in the lattice of $\left[\left(\mathrm{Ph}_{3} \mathrm{P}\right) \mathrm{Au}\right]_{3} \mathrm{Te}^{+} \mathrm{BF}_{4}^{-}, \mathbf{1}$, with atomic numbering. For distances and angles see Table II. 
Table II. Selected atomic distances $[\AA]$ and bond angles $\left[{ }^{\circ}\right]$ in the structure of compound $\mathbf{1}$. (See Figures 1 and 2; standard deviations in parantheses).

\begin{tabular}{llll}
\hline Au1-Au2 & $3.515(1)$ & Au4-Au5 & $3.074(1)$ \\
Au2-Au3 & $3.128(1)$ & Au5-Au6 & $3.3150(1)$ \\
Au1-Au3 & $3.115(1)$ & Au6-Au4 & $3.304(1)$ \\
Au1-Te1 & $2.609(1)$ & Au4-Te2 & $2.614(1)$ \\
Au2-Te1 & $2.610(1)$ & Au5-Te2 & $2.259(1)$ \\
Au3-Te1 & $2.569(1)$ & Au6-Te2 & $2.261(1)$ \\
Au1-Au2' & $3.040(1)$ & Au4-Au6' & $3.308(1)$ \\
Au1-Te1-Au2 & $84.7(1)$ & Au4-Te2-Au5 & $72.6(1)$ \\
Au2-Te1-Au3 & $74.3(1)$ & Au5-Te2-Au6 & $74.9(1)$ \\
Au3-Te1-Au1 & $74.0(1)$ & Au6-Te2-Au4 & $78.6(1)$ \\
\hline
\end{tabular}

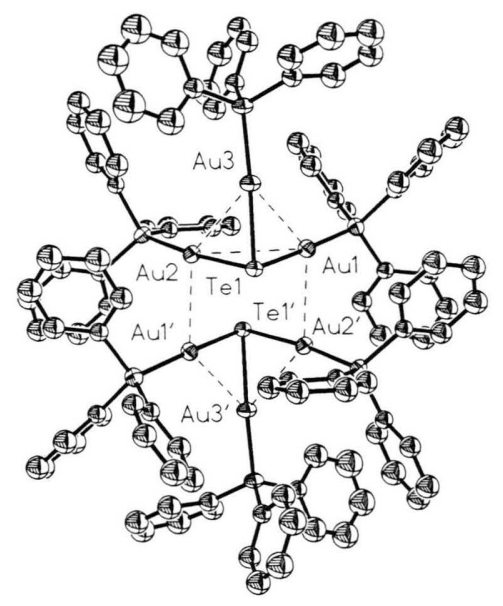

Fig. 2. Dimer of cation A (Figure 1) in the lattice of compound $\mathbf{1}$. The two monomeric units are related by a center of inversion. (The dimer of cation B is analogous.)

$-78{ }^{\circ} \mathrm{C}$ afforded a yellow crystalline product (2) in good yield $(54 \%)$ :

$4\left[\left(\mathrm{Ph}_{3} \mathrm{P}\right) \mathrm{Au}\right] \mathrm{BF}_{4}+\left(t-\mathrm{BuMe}_{2} \mathrm{Si}\right)_{2} \mathrm{Te}+2 \mathrm{thf} \rightarrow$

$2 t-\mathrm{BuMe}_{2} \mathrm{SiF}+2(\mathrm{thf}) \mathrm{BF}_{3}+\left\{\left[\left(\mathrm{Ph}_{3} \mathrm{P}\right) \mathrm{Au}\right]_{4} \mathrm{Te}^{2+}\left(\mathrm{BF}_{4}^{-}\right)_{2}\right.$

The compound decomposes at $103-104{ }^{\circ} \mathrm{C}$ and is soluble in di- and trichloromethane. The Field Desorption mass spectrum shows the cation with $m / z=1504$ as the parent peak, which can be assigned to the trinuclear cation as a stable fragment. In the ${ }^{31} \mathrm{P}\left\{{ }^{1} \mathrm{H}\right\} \mathrm{NMR}$ spectrum of $\mathrm{CDCl}_{3}$ solutions only one sharp signal is observed, with a chemical shift $\delta=39.2 \mathrm{ppm}$, distinctly different from that of compound $\mathbf{1}(\delta=37.9 \mathrm{ppm})$. The ${ }^{1} \mathrm{H}$ NMR spectrum has a phenyl multiplet with a specific fine structure not identical with that of $\mathbf{1}$. The elemental analysis data are in good agreement with the values calculated for the proposed for- mula (2), and therefore there is good reason to assume that the product of reaction (2) is the tetrafluoroborate salt of the tetranuclear telluronium dication (2).

The analogous oxygen [14] and sulfur compounds $[15,16]$ have recently been prepared. The former has a standard tetrahedral structure, but the latter was found to have the dications in a nonclassical square pyramidal configuration.

There is an analogy for this non-conformal behaviour in the pnicogen series, where the tetra(gold)ammonium cations are tetrahedral, while tetra(gold)phosphonium and -arsonium cations are square pyramidal $[16,17]$.

Single crystals of compound $\mathbf{2}$ could not be obtained, and experiments with other phosphine ligands $\left(\mathrm{L}=\mathrm{PPh}_{2} \mathrm{Me}, \mathrm{PMe}_{3}\right)$ did not give stable, crystalline products. Hence structural assignments for compound $\mathbf{2}$ can only be tentative. From the analogies in the poly(gold) chalcogen and pnicogen series, it can be concluded, however, that the tellurium compound also has a square pyramidal structure, in which a tellurium atom is capping a square of gold atoms.

\section{Experimental}

General: All experiments were carried out routinely under an atmosphere of dry nitrogen. Solvents were purified and saturated with nitrogen. Glassware was oven-dried and filled with nitrogen. $\left\{\left[\left(\mathrm{Ph}_{3} \mathrm{P}\right) \mathrm{Au}\right]_{3} \mathrm{O}\right\}^{+} \mathrm{BF}_{4}{ }^{-}[18],\left[\left(\mathrm{Ph}_{3} \mathrm{P}\right) \mathrm{Au}\right]^{+}$ $\mathrm{BF}_{4}{ }^{-}[19]$ and $\left[t-\mathrm{BuMe}{ }_{2} \mathrm{Si}\right)_{2} \mathrm{Te}$ [20] were prepared following literature methods. NMR spectra: Jeol XL 400. Mass spectra: Varian MAT 315.

\section{Tris[(triphenylphosphine)gold(I)]telluronium $(+1)$ tetrafluoroborate (-1) 1}

To a solution of the oxonium salt $(0.25 \mathrm{~g}, 0.17$ $\mathrm{mmol})$ in dichloromethane $(20 \mathrm{~mL})$ was added a solution of $\left(t-\mathrm{BuMe}_{2}\right)_{2} \mathrm{Te}(0.12 \mathrm{~g}, 0.33 \mathrm{mmol})$ in tetrahydrofuran $(10 \mathrm{~mL})$ at $-78^{\circ} \mathrm{C}$. After stirring for $60 \mathrm{~min}$, the product was precipitated by careful addition of pentane $(15 \mathrm{~mL})$. The precipitate was recrystallized from dichloromethane/diethyl ether, yield $0.09 \mathrm{~g}(33 \%)$, yellow crystals, dec. temp. $125-127{ }^{\circ} \mathrm{C} .{ }^{1} \mathrm{H} \mathrm{NMR}\left(\mathrm{CDCl}_{3},-60^{\circ} \mathrm{C}\right): \delta=7.2-$ $7.5 \mathrm{ppm}, \mathrm{m}, \mathrm{Ph} .{ }^{13} \mathrm{C}\left\{{ }^{1} \mathrm{H}\right\} \mathrm{NMR}\left(\mathrm{CDCl}_{3},-60^{\circ} \mathrm{C}\right)$ : $\delta=128.7 \mathrm{ppm}[\mathrm{d}, J(\mathrm{P}, \mathrm{C})=45.1 \mathrm{~Hz}, \mathrm{C} 1], 129.4[\mathrm{~d}$, $J(\mathrm{P}, \mathrm{C})=10.1, \mathrm{C} 3 / 5], 131.9(\mathrm{~s}, \mathrm{C} 4), 133.3[\mathrm{~d}, J(\mathrm{P}, \mathrm{C})=$ 15.2, $\mathrm{C} 2 / 6] .{ }^{31} \mathrm{P}\left\{{ }^{1} \mathrm{H}\right\}$ NMR $\left(\mathrm{CDCl}_{3},-60{ }^{\circ} \mathrm{C}\right): \delta=$ 
37.9 (s). MS (FAB, nitrobenzyl alcohol): $\mathrm{m} / \mathrm{z}=$ $1505\left(\mathrm{M}^{+}, 17 \%\right)$.

$$
\begin{array}{cccc}
\mathrm{C}_{54} \mathrm{H}_{45} \mathrm{Au}_{3} \mathrm{BF}_{4} \mathrm{P}_{3} \mathrm{Te}(1592.18) & \\
\text { Calcd } & \mathrm{C} 40.73 & \mathrm{H} 2.85 & \mathrm{Te} 8.01 \%, \\
\text { Found } & \mathrm{C} 38.83 & \text { H } 2.66 & \text { Te } 8.52 \% .
\end{array}
$$

Crystal structure determination: Details of the structural work are summarized in Table I. Supplementary material has been deposited at Fachinformationszentrum Karlsruhe, D-76344 Eggenstein-Leopoldshafen (CSD 59235).

\section{Tetrakis[(triphenylphosphine)gold(I)]-} telluronium (2+) bis[tetrafluoroborate(-1)] (2)

To a solution of $\left[\left(\mathrm{Ph}_{3} \mathrm{P}\right) \mathrm{Au}\right] \mathrm{BF}_{4}(1.08 \mathrm{~g}, 2.34$ $\mathrm{mmol})$ in tetrahydrofuran $(80 \mathrm{~mL})$ was added a solution of $\left(t-\mathrm{BuMe}_{2} \mathrm{Si}\right)_{2} \mathrm{Te}(0.21 \mathrm{~g}, 0.59 \mathrm{~mL})$ in tetrahydrofuran $(10 \mathrm{~mL})$ at $-78^{\circ} \mathrm{C}$. After strirring for $30 \mathrm{~min}$ the solution was allowed to warm to ambient temperature. A part of the solvent was removed in a vacuum $(c a .50 \mathrm{~mL})$ and the product precipitated from the remaining solution by carefully adding pentane ( $c a .10 \mathrm{~mL}$ ), yield $0.68 \mathrm{~g}$ (54\%), colourless crystals, dec. temp. $103-104{ }^{\circ} \mathrm{C}$. ${ }^{1} \mathrm{H}$ NMR $\left(\mathrm{CDCl}_{3},-60{ }^{\circ} \mathrm{C}\right): \delta=7.0-7.5 \mathrm{ppm}(\mathrm{m}$, $\mathrm{Ph}) .{ }^{31} \mathrm{P}\left\{{ }^{1} \mathrm{H}\right\}$ NMR $\left(\mathrm{CDCl}_{3},-60{ }^{\circ} \mathrm{C}\right): \delta=39.2(\mathrm{~s})$. MS (FD, $\left.\mathrm{CH}_{2} \mathrm{Cl}_{2}\right): m / z=1505\left(\mathrm{M}^{+}-\mathrm{AuPPh}_{3}, 14 \%\right)$.

$$
\begin{array}{cccc}
\mathrm{C}_{72} \mathrm{H}_{60} \mathrm{Au}{ }_{4} \mathrm{~B}_{2} \mathrm{~F}_{8} P_{4} \mathrm{Te}(2138.26) & \\
\text { Calcd } & \mathrm{C} 40.44 & \text { H } 2.83 & \text { Te } 5.97 \% \\
\text { Found } & \mathrm{C} 41.58 & \text { H } 3.12 & \text { Te } 5.70 \% .
\end{array}
$$

[1] G. Tunell, K. Murata, Am. Mineral. 35, 959 (1950) and references therein.

[2] R. C. Haushalter, Inorg. Chim. Acta 102, L37 (1985).

[3] R. C. Haushalter, Angew. Chem., Int. Ed. Engl. 24, 432 (1985).

[4] C. J. Warren, D. M. Ho, A. B. Bocarsly, J. Am. Chem. Soc. 115, 6416 (1993).

[5] S. S. Dhingra, R. C. Haushalter, Inorg. Chem. 33, 2735 (1994)

[6] R. C. Haushalter, J. Chem. Soc., Chem. Commun. 1987, 196.

[7] M. A. Ansari, J. C. Bollinger, J. A. Ibers, J. Am. Chem. Soc. 115, 3838 (1993).

[8] P. J. Bonasia, D. E. Gindelberger, J. Arnold, Inorg. Chem. 32, 5126 (1993).

[9] E. Schulz-Lang, C. Maichle-Mössner, J. Strähle, Z. Anorg. Allg. Chem. 620, 1678 (1994).

[10] H. Schmidbaur, Chem. Soc. Rev. (London) in the press.

[11] a) C. Kowala, J. M. Swan, Aust. J. Chem. 19, 539 (1966):

b) E. W. Abel, C. R. Jenkins, J. Organometal. Chem. 14. 285 (1968);

c) H. Schmidbaur, R. Franke, J. Eberlein, Chem.Ztg. 99, 91 (1975);

d) P. G. Jones, G. M. Sheldrick, E. Hädicke, Acta Crystallogr. B36, 2777 (1980);

e) C. Lensch, P. G. Jones, G. M. Sheldrick, Z. Naturforsch. 37b, 944 (1982); f) P. G. Jones, C. Thöne, Chem. Ber. 123, 1975 (1990) and 124, 2725 (1991);

g) H. Schmidbaur, A. Kolb, E. Zeller, A. Schier, H. Beruda, Z. Anorg. Allg. Chem. 619, 1575 (1993);

h) W. Eikens, C. Kienitz, P. G. Jones, C. Thöne, J. Chem. Soc., Dalton Trans. 1994, 83.

[12] K. Angermaier, H. Schmidbaur, Chem. Ber. 127, 2387 (1994), and references therein; K. Angermaier, Diss., Techn. Univ. Munich (1995).

[13] a) H. Schmidbaur, Gold. Bull. 23, 11 (1990);

b) P. Pyykkö, K. Angermaier, B. Assmann, H. Schmidbaur, J. Chem. Soc., Chem. Commun. 1995, 1889.

[14] H. Schmidbaur, S. Hofreiter, M. Paul, Nature 377, $503(1995)$

[15] F. Canales, M. C. Gimeno, P. G. Jones, A. Laguna, Angew. Chem., Int. Ed. Engl. 33, 769 (1994).

[16] E. Zeller, H. Beruda, A. Kolb, P. Bissinger, J. Riede. H. Schmidbaur, Nature 352, 141 (1991).

[17] R. Bachmann, H. Schmidbaur, Inorg. Chem. in press.

[18] A. N. Nesmeyanov, E. G. Perevalova, Y. T. Struchkov, M. Y. Antipin, K. I. Grandberg, V. P. Dyadchenko, J. Organometal. Chem. 201, 343 (1980).

[19] From equimolar quantities of $\mathrm{Ph}_{3} \mathrm{PAuCl}$ and $\mathrm{AgBF}_{4}$ in tetrahydrofuran at $-78^{\circ} \mathrm{C}$. After $2 \mathrm{~h}$ of stirring. the precipitate is allowed to settle, and the solution is decanted.

[20] M. R. Detty, M. D. Seidler, J. Org. Chem. 47, 1354 (1982). 